NASA/TM-1999-209399

\title{
Analyses of Contaminated Solar Array Handrail Samples Retrieved from Mir
}

Kim K. de Groh

Glenn Research Center, Cleveland, Ohio

Terry R. McCue

Dynacs Engineering Company, Inc., Brook Park, Ohio 
Since its founding, NASA has been dedicated to the advancement of aeronautics and space science. The NASA Scientific and Technical Information (STI) Program Office plays a key part in helping NASA maintain this important role.

The NASA STI Program Office is operated by Langley Research Center, the Lead Center for NASA's scientific and technical information. The NASA STI Program Office provides access to the NASA STI Database, the largest collection of aeronautical and space science STI in the world. The Program Office is also NASA's institutional mechanism for disseminating the results of its research and development activities. These results are published by NASA in the NASA STI Report Series, which includes the following report types:

- TECHNICAL PUBLICATION. Reports of completed research or a major significant phase of research that present the results of NASA programs and include extensive data or theoretical analysis. Includes compilations of significant scientific and technical data and information deemed to be of continuing reference value. NASA's counterpart of peerreviewed formal professional papers but has less stringent limitations on manuscript length and extent of graphic presentations.

- TECHNICAL MEMORANDUM. Scientific and technical findings that are preliminary or of specialized interest, e.g., quick release reports, working papers, and bibliographies that contain minimal annotation. Does not contain extensive analysis.

- CONTRACTOR REPORT. Scientific and technical findings by NASA-sponsored contractors and grantees.
- CONFERENCE PUBLICATION. Collected papers from scientific and technical conferences, symposia, seminars, or other meetings sponsored or cosponsored by NASA.

- SPECIAL PUBLICATION. Scientific, technical, or historical information from NASA programs, projects, and missions, often concerned with subjects having substantial public interest.

- TECHNICAL TRANSLATION. Englishlanguage translations of foreign scientific and technical material pertinent to NASA's mission.

Specialized services that complement the STI Program Office's diverse offerings include creating custom thesauri, building customized data bases, organizing and publishing research results ... even providing videos.

For more information about the NASA STI Program Office, see the following:

- Access the NASA STI Program Home Page at http://www.sti.nasa.gov

- E-mail your question via the Internet to help@sti.nasa.gov

- Fax your question to the NASA Access Help Desk at (301) 621-0134

- Telephone the NASA Access Help Desk at (301) 621-0390

- Write to:

NASA Access Help Desk

NASA Center for AeroSpace Information 7121 Standard Drive

Hanover, MD 21076 
NASA/TM-1999-209399

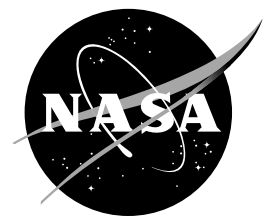

\section{Analyses of Contaminated Solar Array Handrail Samples Retrieved from Mir}

Kim K. de Groh

Glenn Research Center, Cleveland, Ohio

Terry R. McCue

Dynacs Engineering Company, Inc., Brook Park, Ohio

Prepared for the

34th Intersociety Energy Conversion Engineering Conference sponsored by the Society of Automotive Engineers

Vancouver, British Columbia, Canada, August 1-5, 1999

National Aeronautics and

Space Administration

Glenn Research Center 


\section{Acknowledgments}

The authors would like to thank the MIR Solar Array Return Experiment (SARE) U.S. and Russian team participants for providing the opportunity to study the retrieved Mir Solar array handrail samples. Thanks also go to Tim Skowronski of Cleveland State University for taking the color photographs.

Available from

NASA Center for Aerospace Information 7121 Standard Drive

Hanover, MD 21076

Price Code: A03
National Technical Information Service 5285 Port Royal Road Springfield, VA 22100 Price Code: A03 


\title{
Analyses of Contaminated Solar Array Handrail Samples Retrieved from Mir
}

\author{
Kim K. de Groh \\ National Aeronautics and Space Administration \\ Glenn Research Center \\ Cleveland, Ohio 44135 \\ Terry R. McCue \\ Dynacs Engineering Company, Inc. \\ Brook Park, Ohio 44142
}

\begin{abstract}
Summary
In January 1998 during the STS-89 mission, an eight section Russian solar array panel was retrieved after more than ten years exposure to the orbital space environment on the Russian space station Mir. Two darkened handrail samples from the Russian solar array have been evaluated for contamination; a section of a white paint covered rigid handrail and a section of woven fabric over-wrapped around a flexible handhold. The handrail samples were evaluated using optical microscopy (OM), field emission scanning electron microscopy (FESEM) and energy dispersive spectroscopy (EDS). Optical properties were also obtained. Microscopy has shown the discolored areas to have thick layers of contaminant that has crazed and spalled off in regions. Energy dispersive spectroscopy revealed that the brown contaminant is composed of oxidized silicon. No silicon was present on the unexposed fabric over-wrap, and very small amounts were present in the white paint. Therefore, the contaminant layer on both samples is attributed to silicone contamination from other spacecraft materials that have been oxidized by atomic oxygen while in orbit. A significant source of the silicone contamination appears to be from the solar array itself.
\end{abstract}

\section{Introduction}

In January 1998 during the shuttle STS-89 mission, an eight section Russian solar array panel was retrieved after more than ten years exposure to the orbital space environment on Mir. The operational array had been located on the Mir core module, located directly above the Kvant-2 module. The retrieved array segment is shown in figure 1 as it had been located on the Mir Space Station. The 8-panel section was part of a 32 panel array. The array was deployed June 16, 1987 and was removed on November 3, 1997 (ref. 1). The array had been actively used as a source of electrical power for 8 years. The retrieval of the array provided a unique opportunity to study the effects of the low Earth orbit (LEO) environment on a functional solar array. The intact solar array underwent scientific inspections and preliminary tests by a joint team of U.S. and Russian investigators to evaluate the effects of long term space exposure (ref. 1). Upon initial examination, significant contamination was observed over most components of the array. One panel, panel 8, was provided to the U.S. scientists for further evaluation (refs. 1 and 2). The backside of panel 8 is shown in figure 2. Panel 8 was located farthest away from the Mir core module. Results of analyses (power degradation studies, impact assessment, optical properties and contamination) of the solar array panel by the U.S. team are reported by Visentine et al. (ref. 1).

As part of the U.S. investigations, two solar array handrail samples from panel 8 were evaluated for contamination at NASA Glenn Research Center and are reported here. One is a section of the rigid handrail, and the second is a section of woven fabric tape that was over-wrapped around a flexible handhold. Both the flexible handhold woven fabric and the rigid handrail were significantly darkened after 10 years of space exposure. The handrail samples have been evaluated using optical microscopy (OM), field emission scanning electron microscopy (FESEM) and energy dispersive spectroscopy (EDS). Solar absorptance and room temperature emittance values were also obtained.

The returned contaminated solar array segment is very similar in design to the solar arrays being supplied by the Russians for the International Space Station (ISS). Therefore, it was desirable to determine what the contaminants on various surfaces are, and what the sources of the contamination were. 


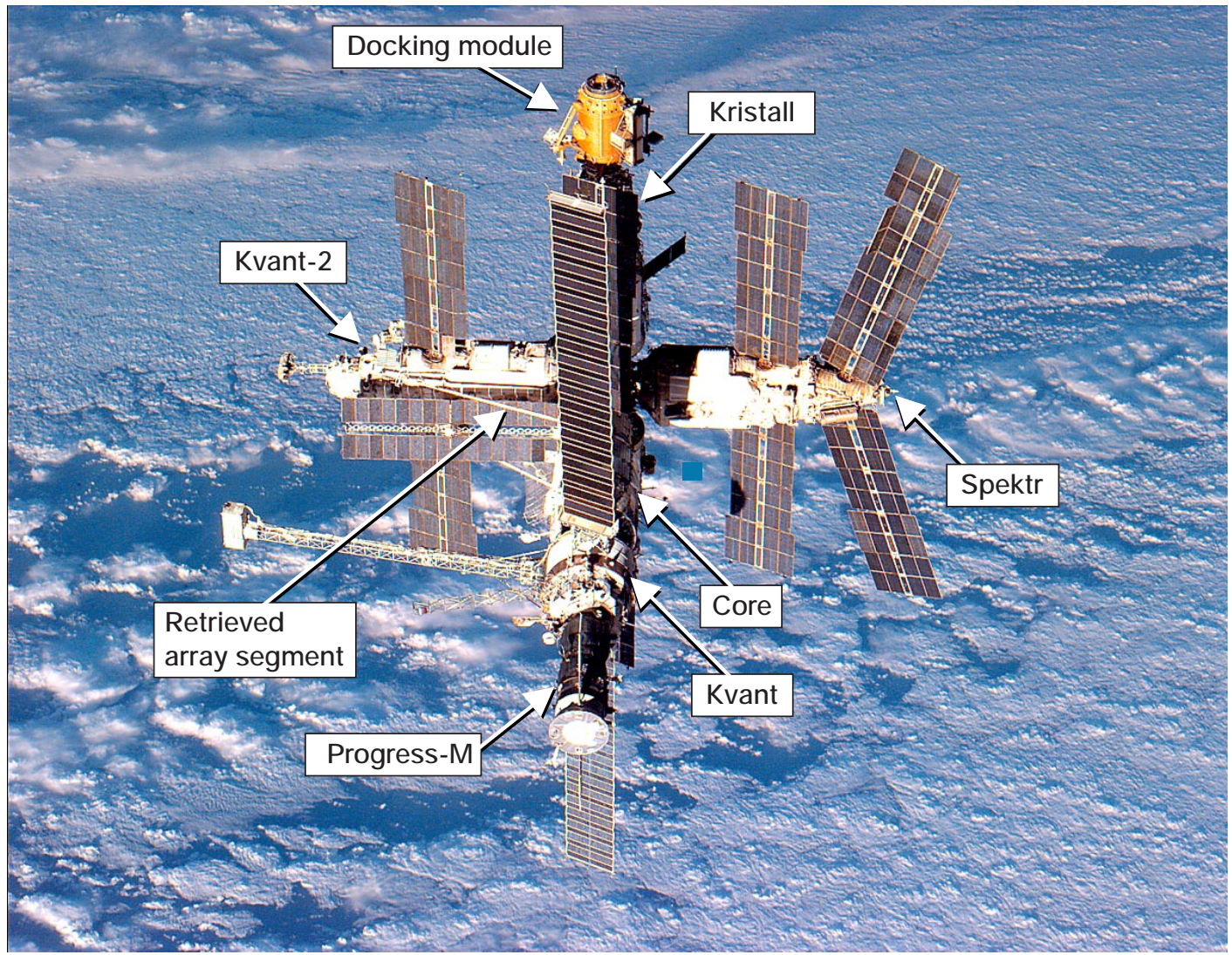

Figure 1. Photograph of the Mir Space Station taken during the STS-79 mission showing the location of the solar array segment that was retrieved.

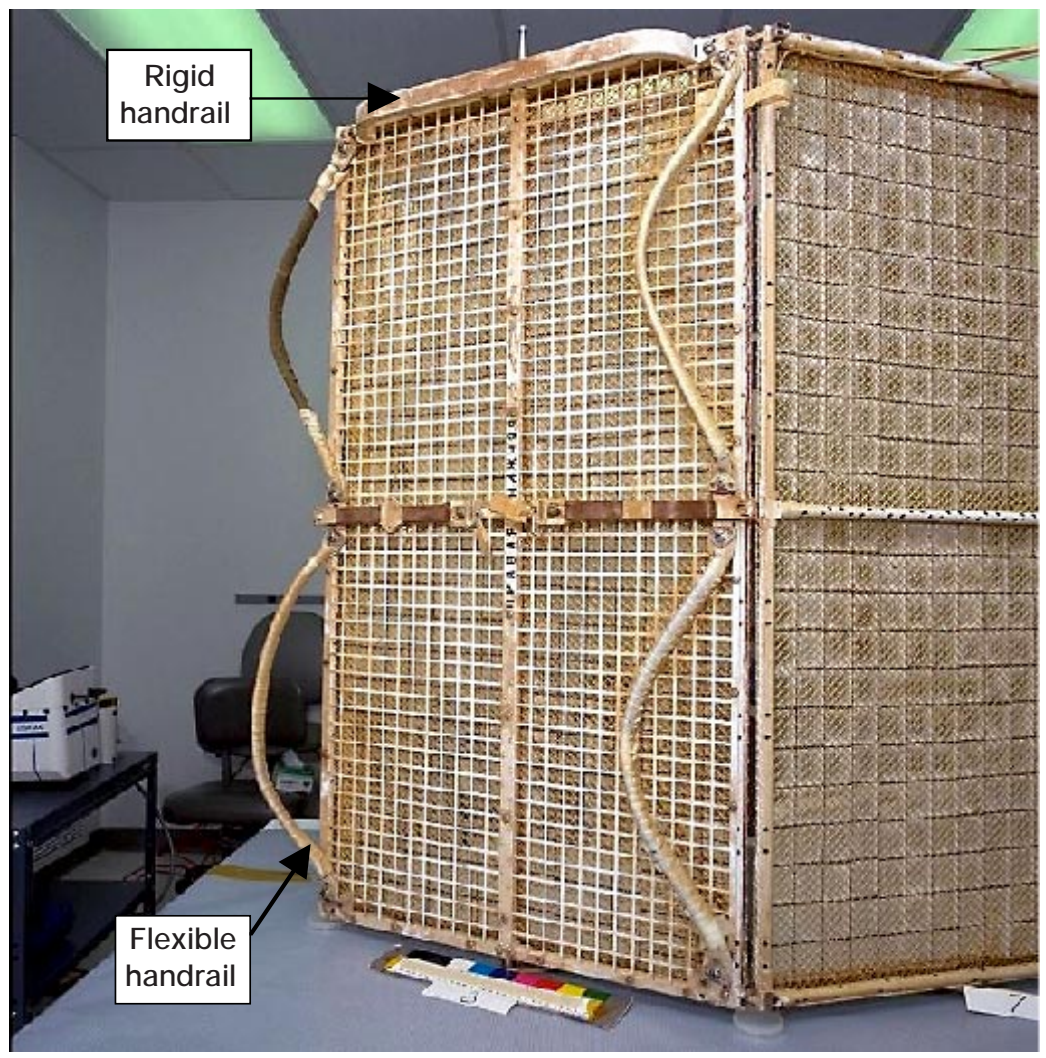

Figure 2. Backside of the retrieved Mir solar array, panel 8 (ref. 2). 


\section{Materials and Experimental Procedures}

\section{Materials}

Rigid Handrail Sample. The rigid handrail can be seen at the top of panel 8 in figure 2. The handrail is an aluminum rectangular hollow bar $(\sim 1.6 \times 3.2 \mathrm{~cm}$ cross-section $)$ coated with a white thermal control paint. The white paint is believed to be the Russian paint AK-573 whose components consist of silicone and acrylic binders with a $\mathrm{ZnO}$ white pigment (ref. 1). The nonuniform discoloration of the previously white handrail is visible in figure 2. Two sections were provided for analyses. One section was a curved end of the handrail and was labeled "zeropoint." This curved handrail section had streaky, nonuniform brown discoloration on the space-facing side of the handrail, and two distinct very uniform discolored sections, dark tan and dark brown, on the array facing side of the handrail. The space-facing and array facing sides of the curved handrail section are shown in figure 3(a) and 3 (b), respectively. The second sample was cut from the flat section of the handrail (a $2.54 \mathrm{~cm}$ wide section). This sample was discolored on all sides of the exterior surfaces. The smaller surfaces, positioned perpendicular to the array, are dark tan, while the larger surfaces, array-facing or space-facing, are dark brown. One of the larger surfaces (side A) was more uniform in color than the other side and appeared to have faced the solar array based on similarity in appearance to the curved section. The space-facing side of the flat rigid handrail sample is shown in figure 4 .

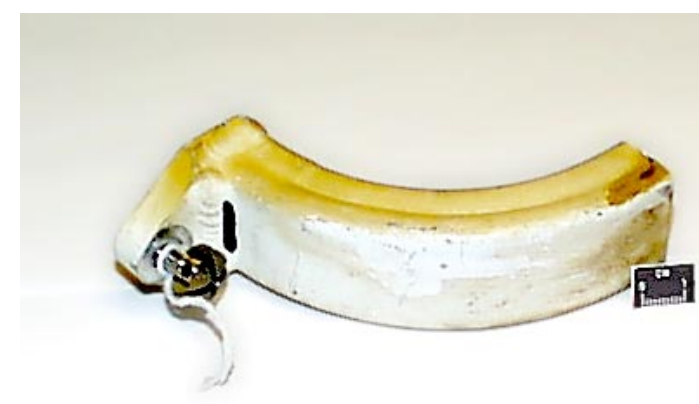

(a)

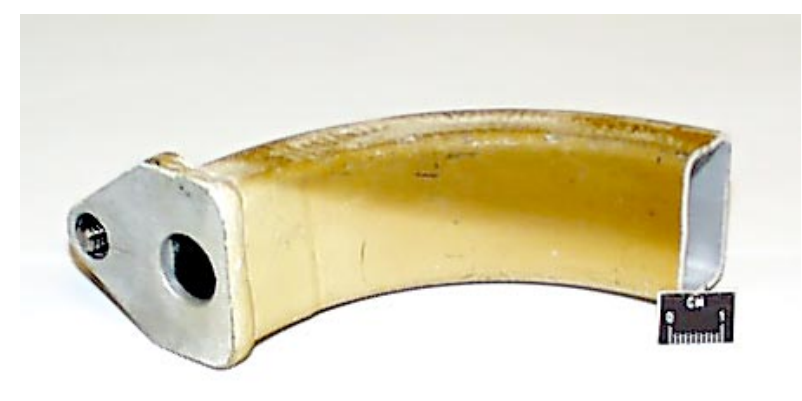

(b)

Figure 3. Curved rigid handrail sample. (a) Space-facing side of sample. (b) Array-facing side of sample.

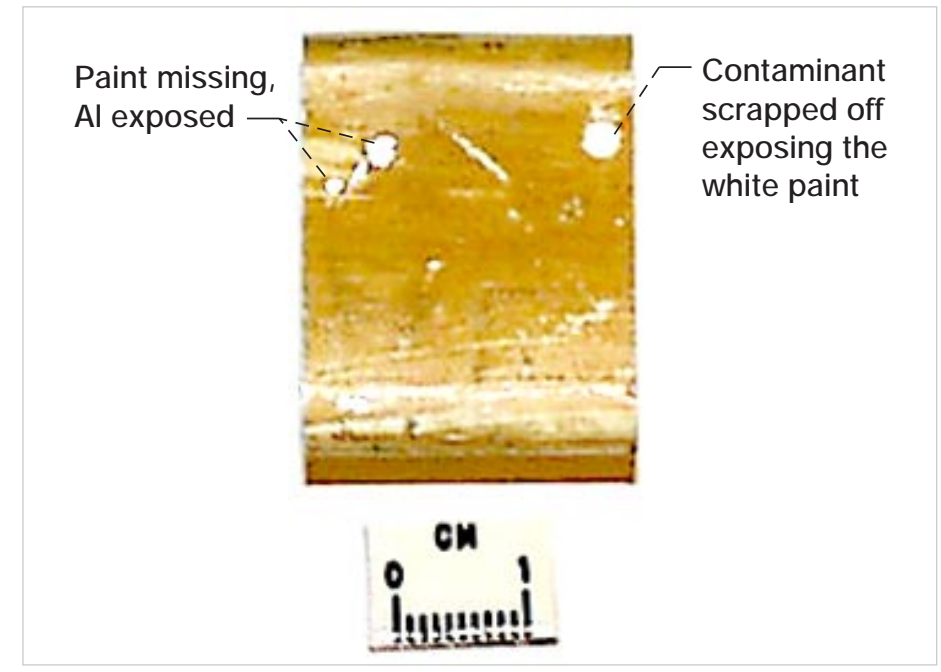

Figure 4. The space-facing side of the flat rigid handrail sample. 
Flexible Handhold Over-Wrap Tape. The flexible handhold over-wrap tape sample was from one of the four flexible handholds. These flexible handholds can be seen in figure 2 . This woven polymeric fabric was wrapped in an overlapping manner such that half of the width of the material was shielded from space exposure, and appears white, while the exposed half is discolored light brown. A close-up of the over-wrap tape on one of the flexible handholds can be seen in figure 5. The over-wrap tape sample which was provided for analyses is shown in figure 6 .

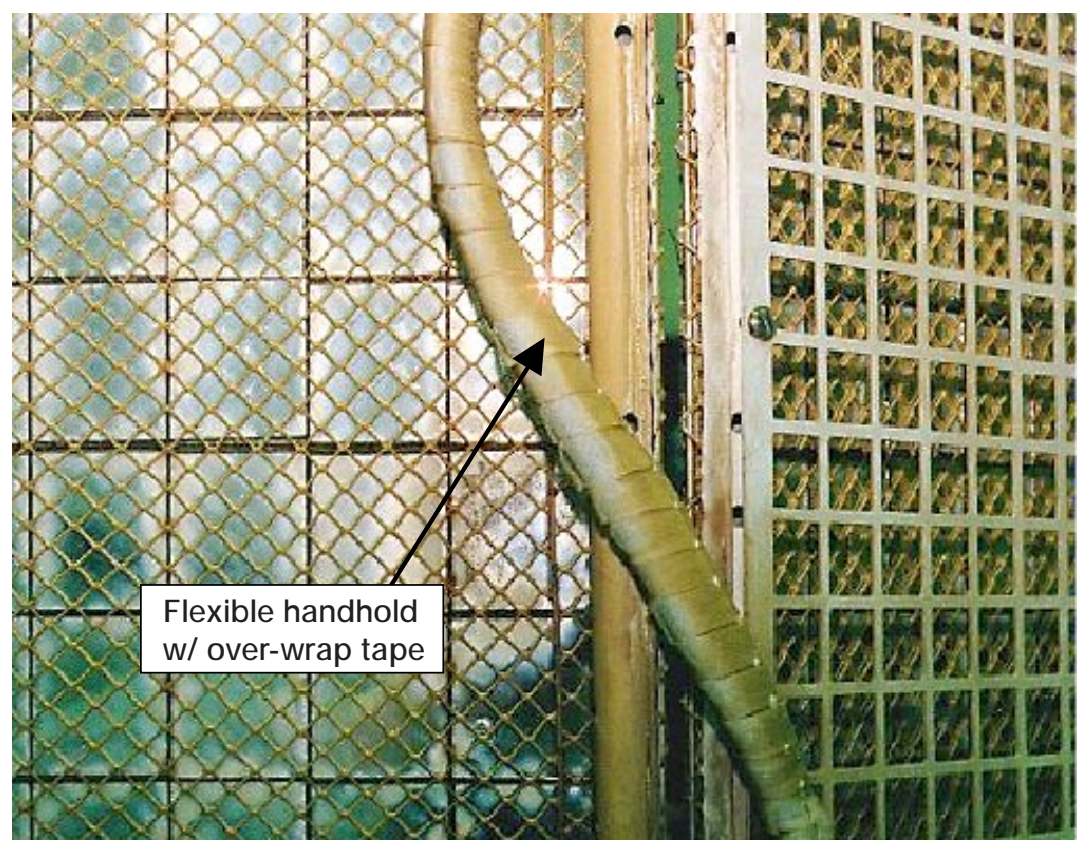

Figure 5. Close-up of a flexible handhold showing the over-wrap tape (ref. 2).
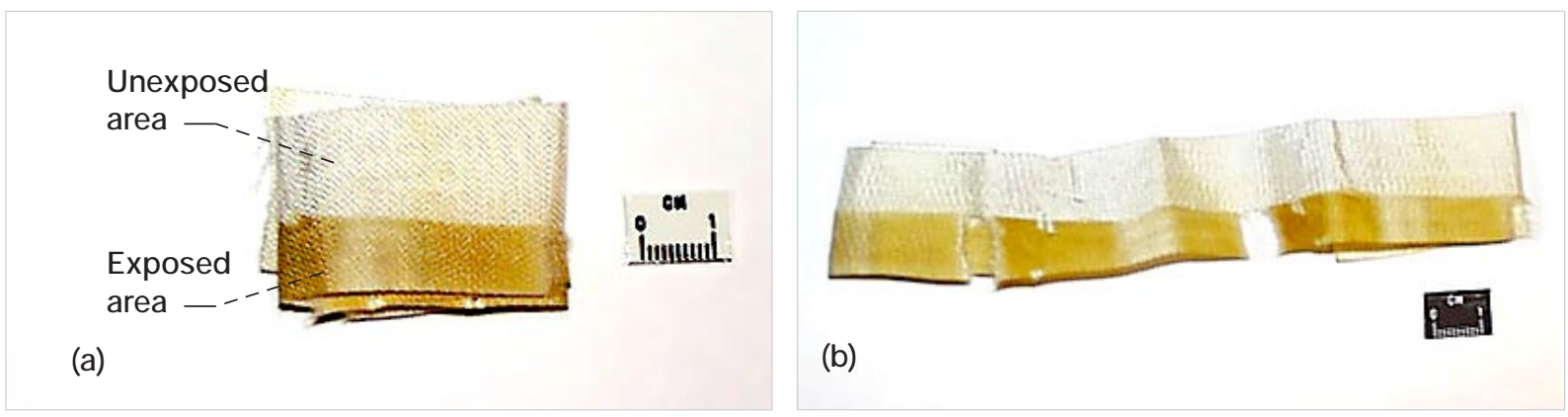

Figure 6. Flexible handhold over-wrap tape sample. (a) Sample as provided, folded onto itself. (b) Sample opened up.

\section{Optical Properties}

Solar integrated total reflectance $\left(\rho_{t}\right)$, solar absorptance $\left(\alpha_{\mathrm{s}}\right)$, and room temperature emittance $\left(\varepsilon_{\mathrm{RT}}\right)$ were obtained for the two sides of the flat rigid handrail sample. Reflectance and $\alpha_{\mathrm{s}}$ were obtained for the unexposed and exposed areas of the woven tape. Emittance of the woven tape could not be obtained due to the limited size of the exposed and unexposed areas. Spectral reflectance was obtained using a Perkin-Elmer $\lambda$-19 Spectrophotometer operated with a $150 \mathrm{~mm}$ integrating sphere. Total reflectance was obtained from 250 to $2500 \mathrm{~nm}$, and the data were convoluted into the air mass zero solar spectrum to obtain solar integrated values. Solar absorptance was calculated 
by subtracting $\rho_{\mathrm{t}}$ from 1 because the samples were opaque (the fabric was layered on top of itself so that it was opaque). Room temperature emittance was obtained using a Gier Dunkel DB-100 infrared reflectometer which provided an integrated reflectance value which was then subtracted from 1 to get $\varepsilon_{\mathrm{RT}}$.

\section{Surface Characterization}

Optical Microscopy. Optical micrographs of both the array-facing and space-facing sides of the rigid handrail sample, and the exposed and unexposed areas of the handhold tape sample were taken on an Olympus SZH Stereozoom microscope.

Field Emission Scanning Electron Microscopy (FESEM) and Energy Dispersive Spectroscopy (EDS). Images of the handhold over-wrap tape fabric and a darkened piece of paint that was chipped off of the rigid handrail sample were obtained using a Hitachi S-4700 Field Emission Scanning Electron Microscope operated at 10 to $15 \mathrm{kV}$. Because of the interest in conducting analytical analyses, samples were imaged without applying conductive films. Imaging was obtained in backscattered electron mode. Energy dispersive spectroscopy was conducted using an EDAX DX Prime system. The contaminated over-wrap fabric sample was coated with a conductive film after EDS analyses and imaged in secondary electron mode for atomic oxygen erosion studies.

\section{Results}

\section{Optical Properties}

The results of optical property characterization are provided in table I. The surface browning has increased the solar absorptance of both types of handrail samples significantly. The solar absorptance of unexposed AK-573 is 0.294 (ref. 1). The solar absorptance of the darkened handrail paint was 0.537 to 0.555 , an increase of 0.243 to 0.261 . The spectral reflectance of the solar array facing side of the handrail sample is shown in figure 7 . The flexible handrail over-wrap fabric had an increase in absorptance of 0.14 in the exposed area compared to the unexposed area. The total reflectance spectral data for the exposed and unexposed areas are shown together in figure 8 .

TABLE I. OPTICAL PROPERTIES OF MIR HANDRAIL SAMPLES.

\begin{tabular}{|l|c|c|}
\hline \multicolumn{1}{|c|}{ Sample } & $\alpha_{\mathrm{s}}$ & $\varepsilon_{\mathrm{RT}}$ \\
\hline Flat handrail, Side A & 0.537 & 0.832 \\
\hline Flat handrail, Side B & 0.555 & 0.836 \\
\hline Handhold tape, unexposed side & 0.330 & --- \\
\hline Handhold tape, exposed side & 0.465 & --- \\
\hline
\end{tabular}

\section{Optical Microscopy}

Rigid Handrail Sample (Flat Section). The uniformly dark brown side (array facing side) of the flat handrail sample had a rainbow hue and was clearly crazed, as can be seen in figure 9 . Although the space-facing side of the handrail was also brown, its surface did not have a rainbow hue and was not crazed, as can be seen in figure 10 . Surface "holes" were observed on the space-facing side (see fig. 10). These holes are believed to be the result of air pockets produced during the painting process. After close examination, these holes appear present on the array facing side, faintly visible underneath the thick contaminant layer. 


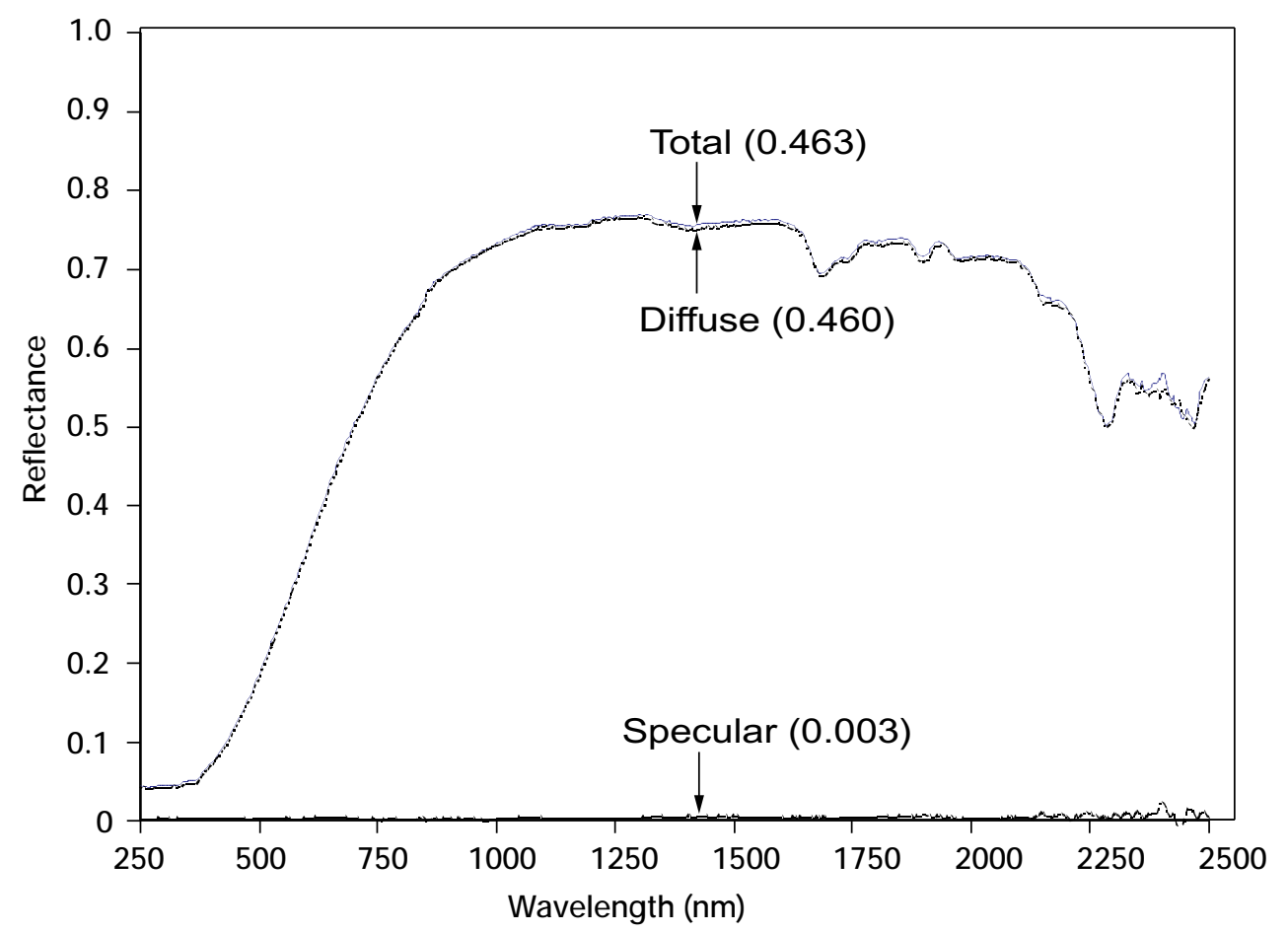

Figure 7. Spectral reflectance for the solar array facing side (side A) of the rigid handrail sample.

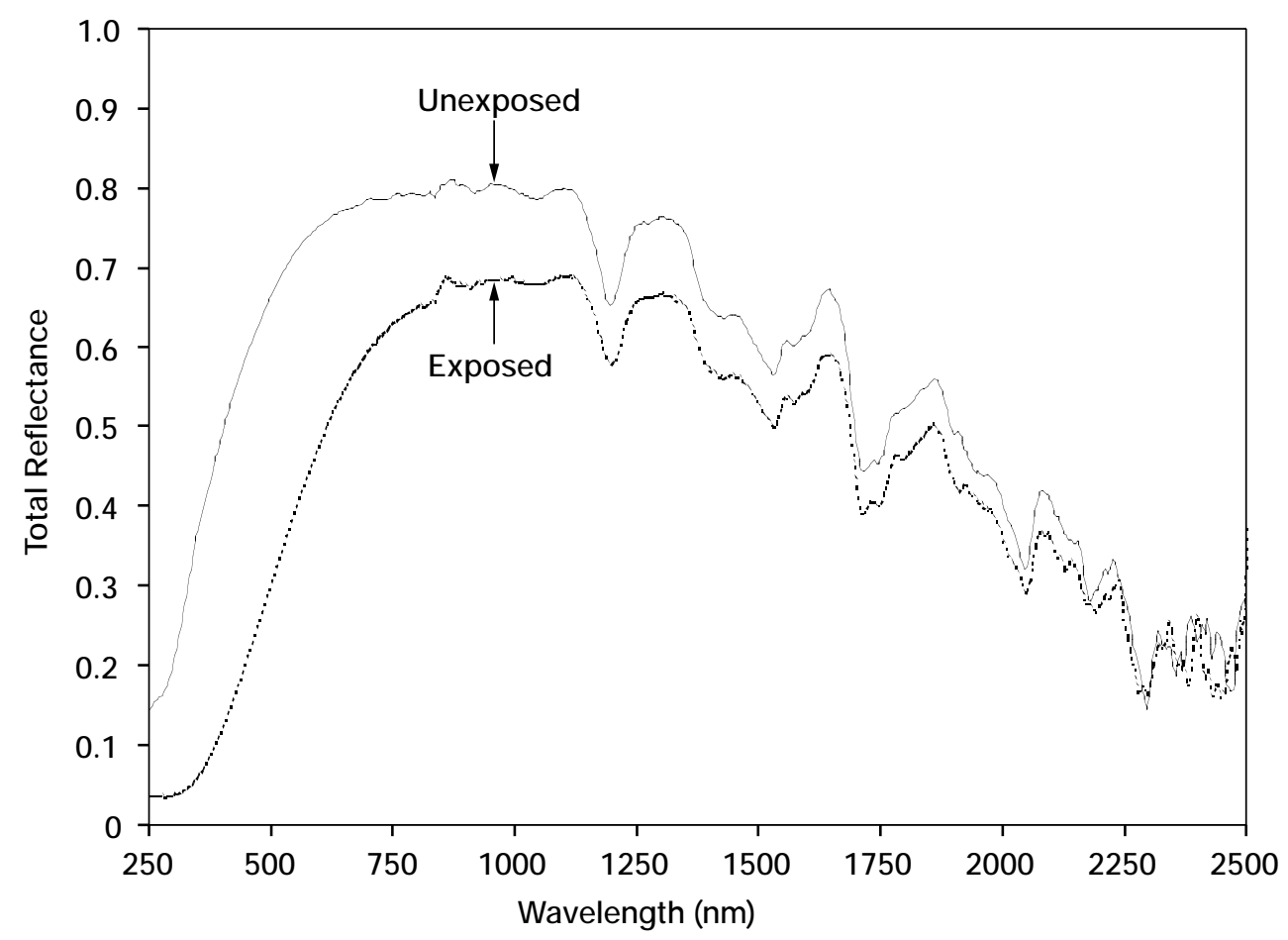

Figure 8. Total reflectance for unexposed $\left(\alpha_{s}=0.330\right)$ and exposed $\left(\alpha_{s}=0.465\right)$ areas of the flexible handhold tape over-wrap fabric. 


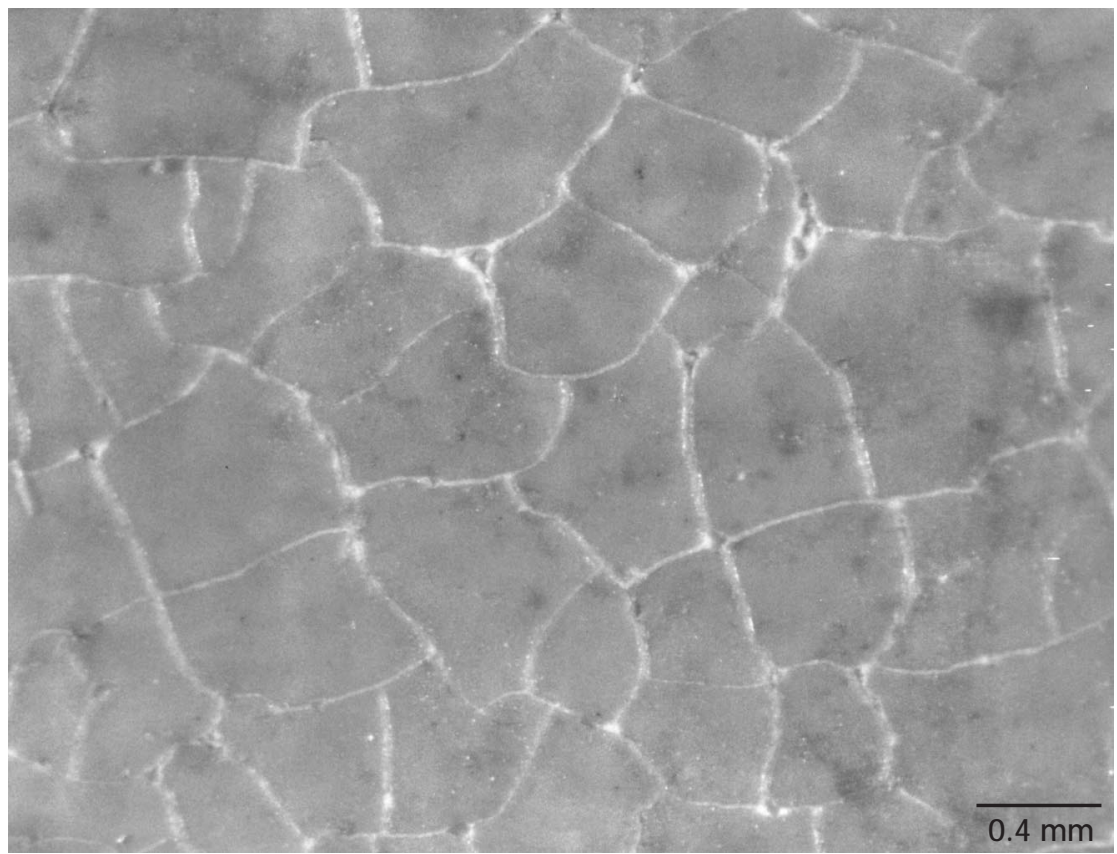

Figure 9. Side A (array-facing side) of the rigid handrail showing crazing of the brown contaminant layer.

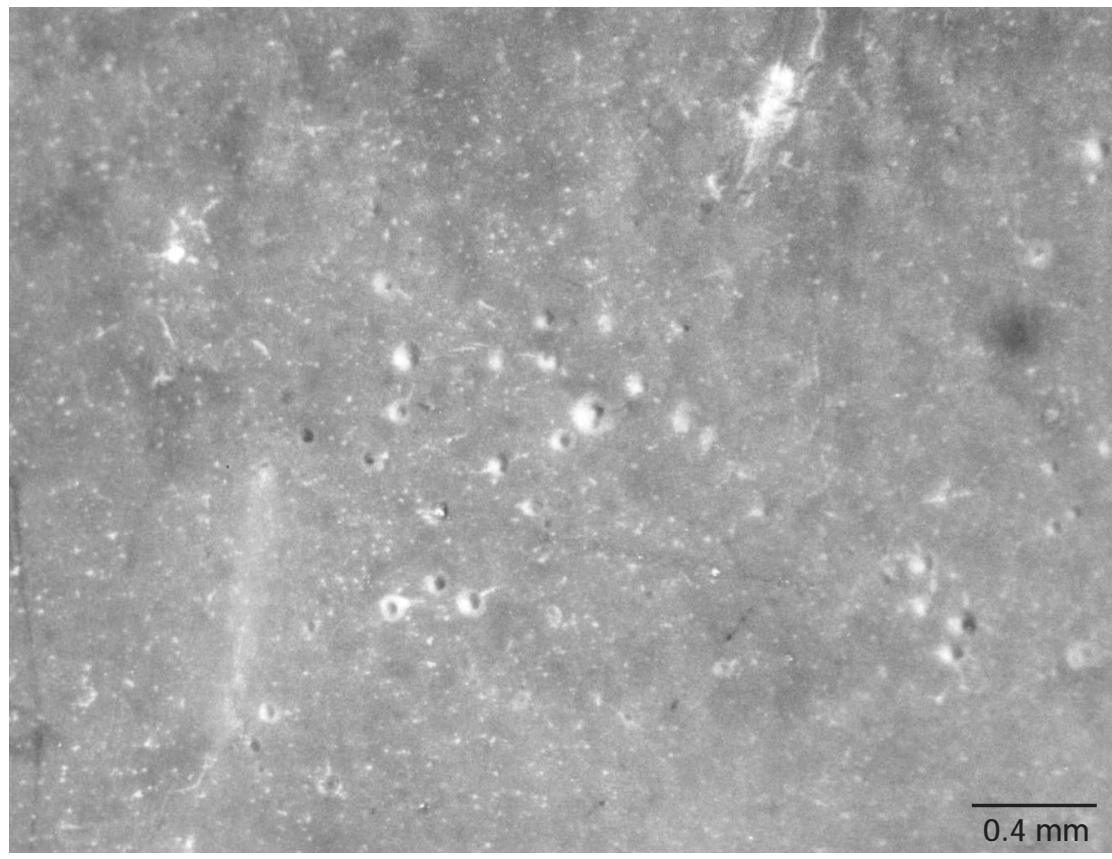

Figure 10. Side B (space-facing side) of the rigid handrail. The brown contaminant layer is not crazed on this surface. 
Flexible Handhold Over-Wrap Tape. Optical microscopy examination of the exposed, brown region of the handhold tape fabric revealed micro-crazing of a contamination layer, as shown in figure 11. This crazed layer is not present on the protected, unexposed region that has an off-white color (see fig. 12).

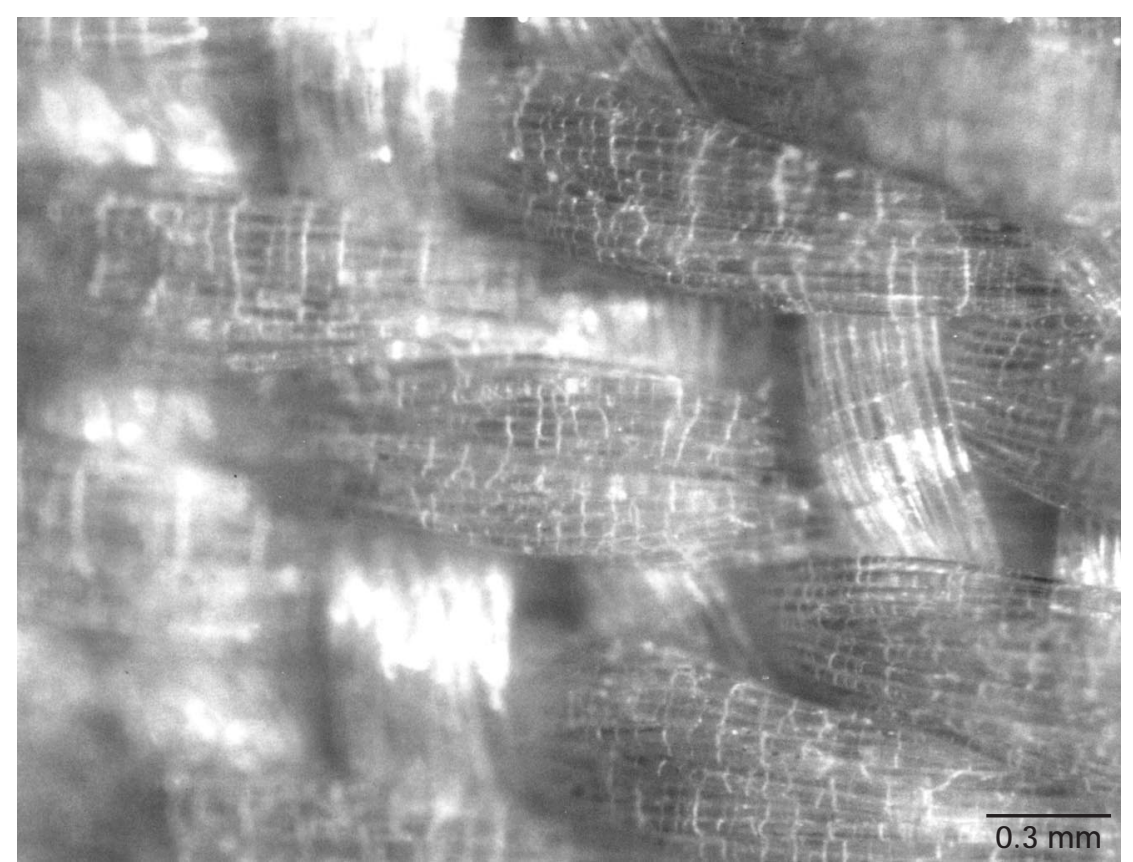

Figure 11. Micro-crazing of the brown contaminant layer on the exposed area of the flexible handhold over-wrap tape fabric.

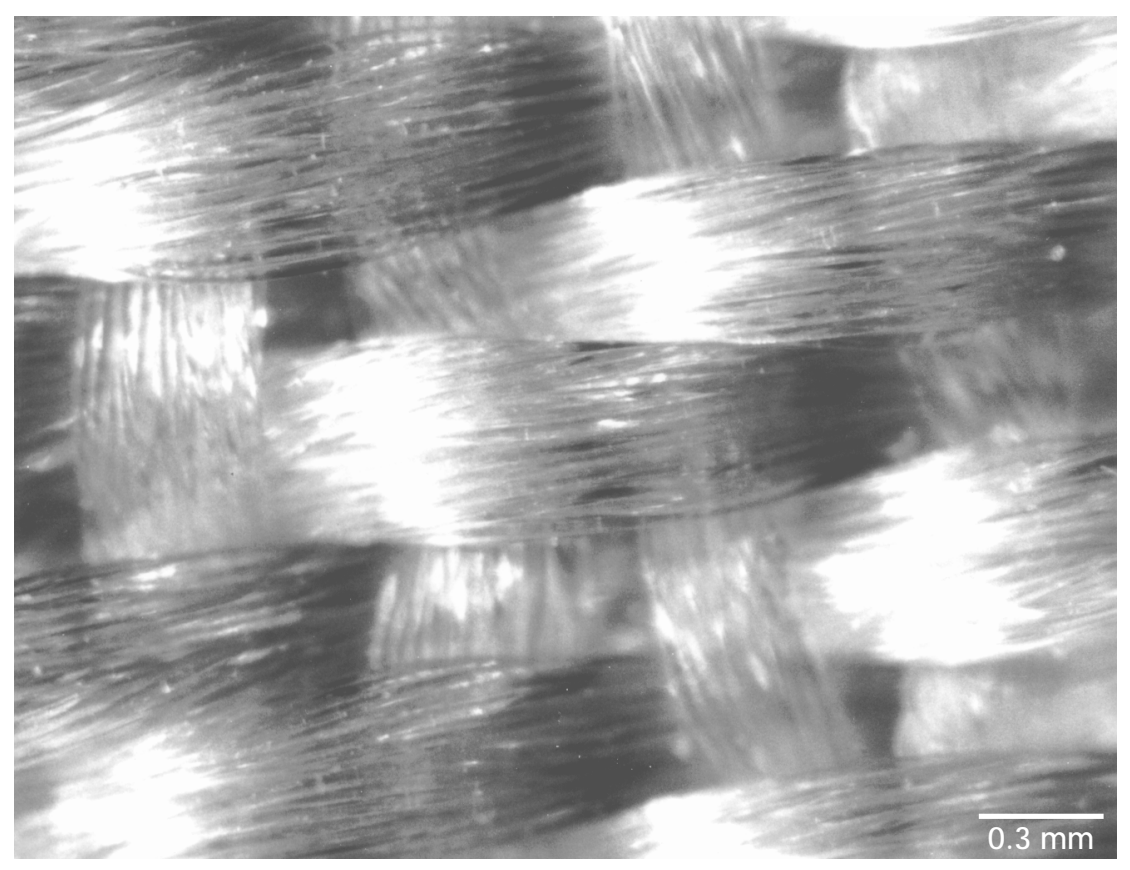

Figure 12. Protected, white side of the flexible handhold over-wrap tape fabric. 
Field Emission Scanning Electron Microscopy (FESEM) and Energy Dispersive Spectroscopy (EDS)

Rigid Handrail Sample (Paint Chip Sample). A flake of paint containing the brown contaminant stain was easily removed from the flat handrail sample for FESEM imaging. The sample was broke into two pieces, which exposed a clean white cross-section surface for analysis. The image and the corresponding EDS spectra for the cross-sectioned clean paint surface are shown in figures 13 and 14, respectively. The image shows a very rough porous surface. The spectra indicates that the paint consists primarily of $\mathrm{Zn}, \mathrm{O}$ and $\mathrm{C}$, with small amounts of $\mathrm{Si}, \mathrm{Ti}$ and Al. These results appear to be consistent with the Russian white paint TP-CO-02, which contains $\mathrm{Al}$ and Ti in addition to $\mathrm{Zn}, \mathrm{O}$ and $\mathrm{Si}$ which are found in AK-573 (ref. 3). In backscattered imaging, dark areas were observed and were found to be composed primarily of $\mathrm{Ti}$ and $\mathrm{Zn}$, with a little $\mathrm{O}$.

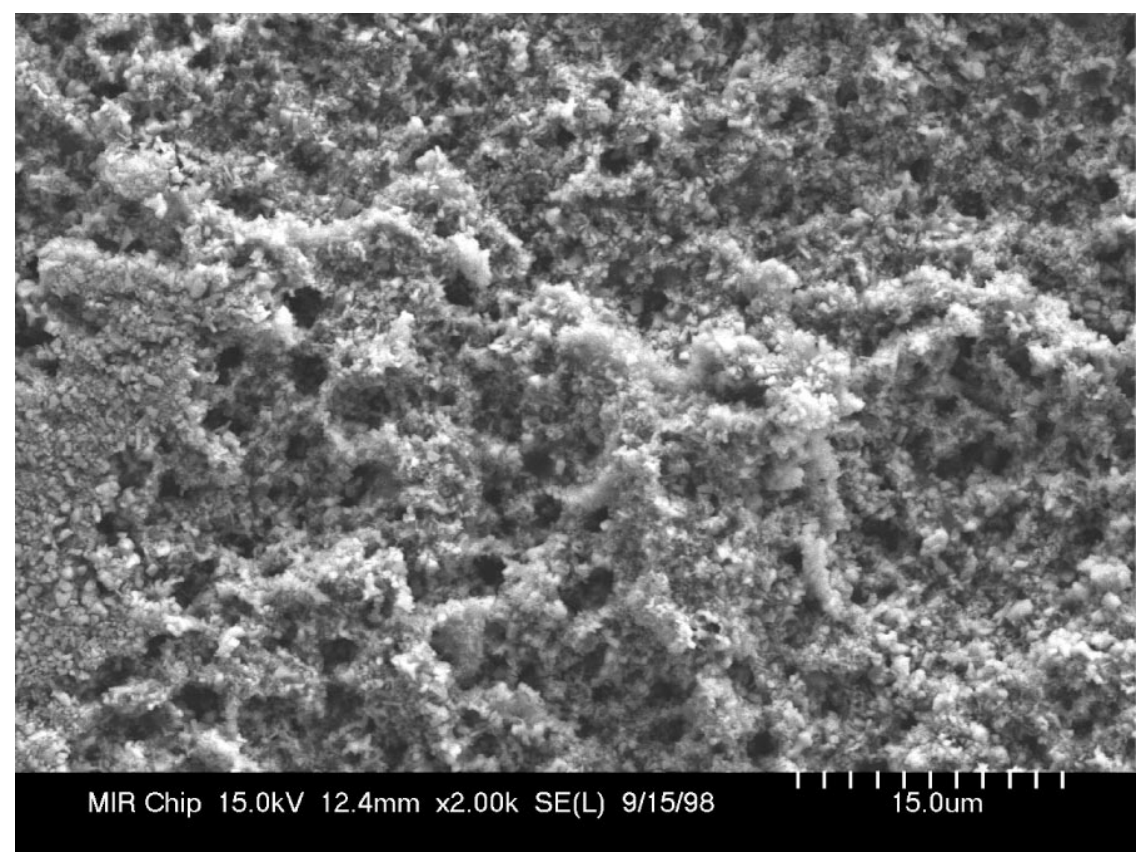

Figure 13. Cross-sectioned surface of the rigid handrail white paint.

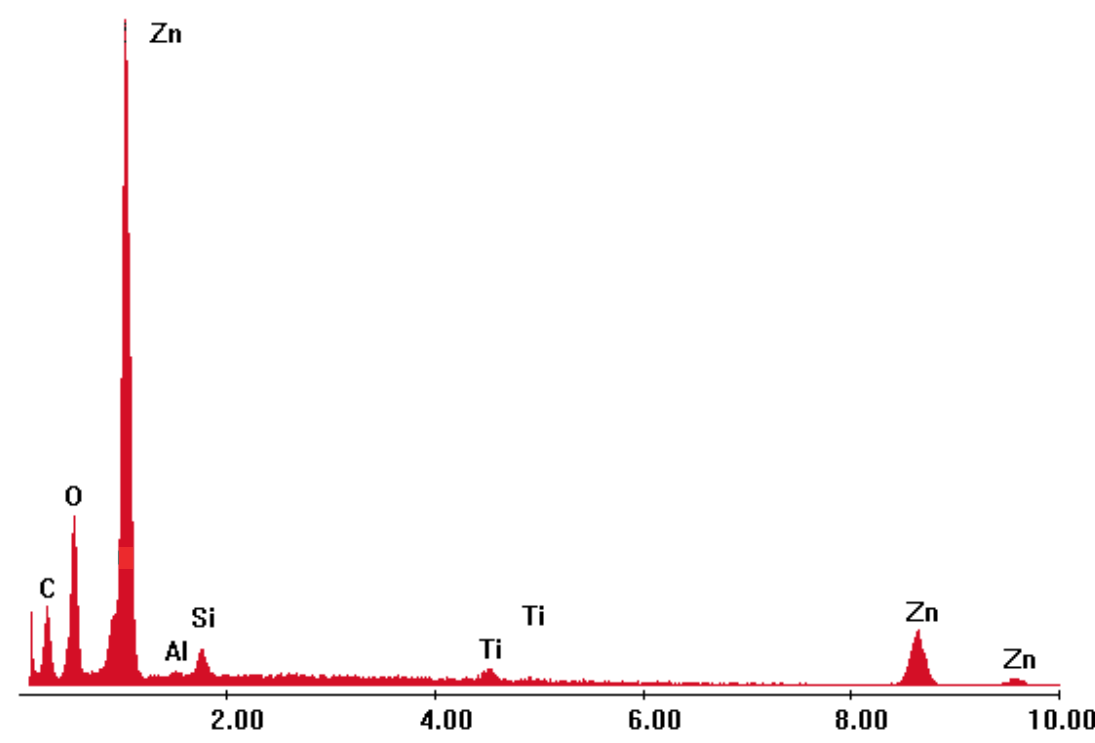

Figure 14. EDS spectra of the cross-sectioned paint sample shown in Figure 13. 
An image of the brown contaminated surface of the paint chip is shown in figure 15. There appears to be a contaminant layer that is crazed and has spalled off the surface in areas. EDS point spectra were taken on a flaked-off contaminant piece (point A) and on an area where the contaminant layer appears to be missing (point B), as shown in figures 16 and 17, respectively. The contaminant layer is composed primarily of oxidized silicon (from silicone contamination). These results are consistent with electron spectroscopy for chemical analysis (ESCA) measurements reported by Visentine, et al. (ref. 1). Point $\mathrm{B}$ is composed of $\mathrm{C}, \mathrm{O}, \mathrm{Zn}$ and $\mathrm{Ti}$, with small amounts of $\mathrm{Si}, \mathrm{Al}$ and an unknown element, possibly $\mathrm{Pb}$. The oxidized silicon layer has spalled off the surface in this region, and the surface has a strong $\mathrm{C}$ and $\mathrm{O}$ presence.

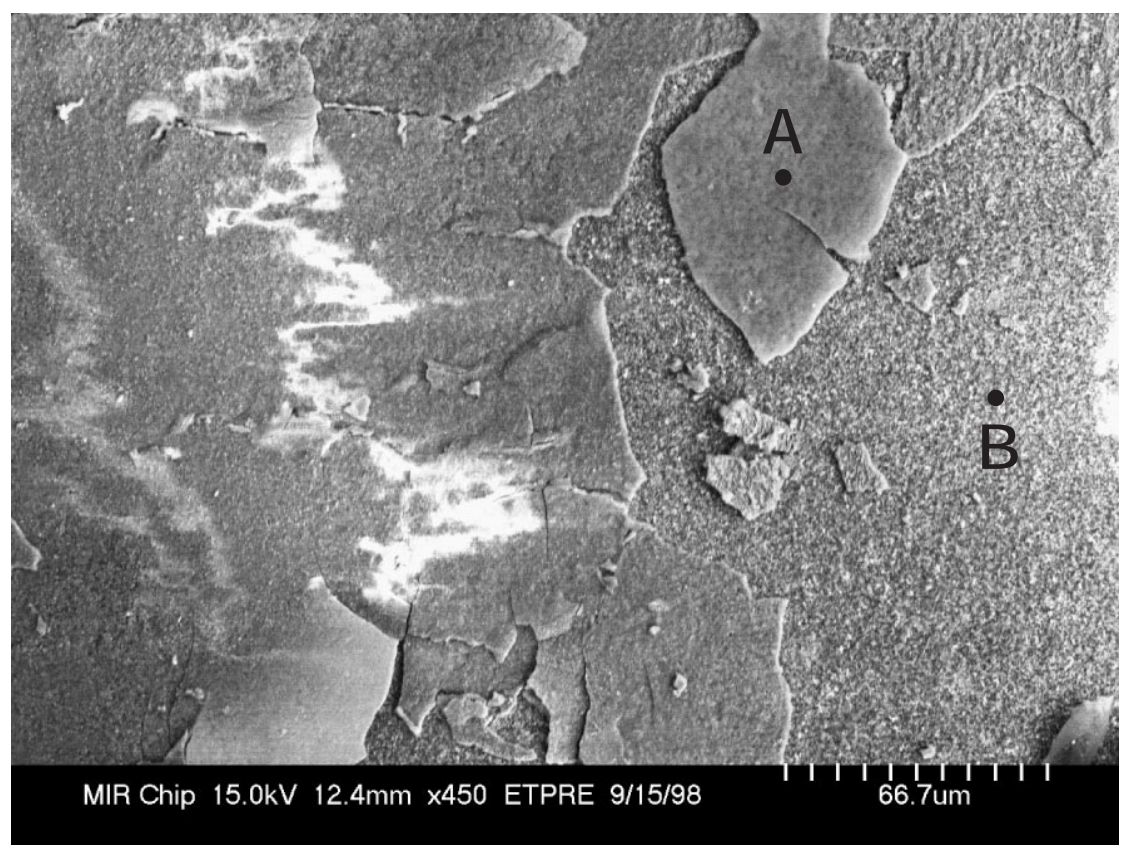

Figure 15. B rown stained area on the surface of the rigid handrail sample. The contaminant layer is crazed and has lifted up, or spalled off, in certain areas.

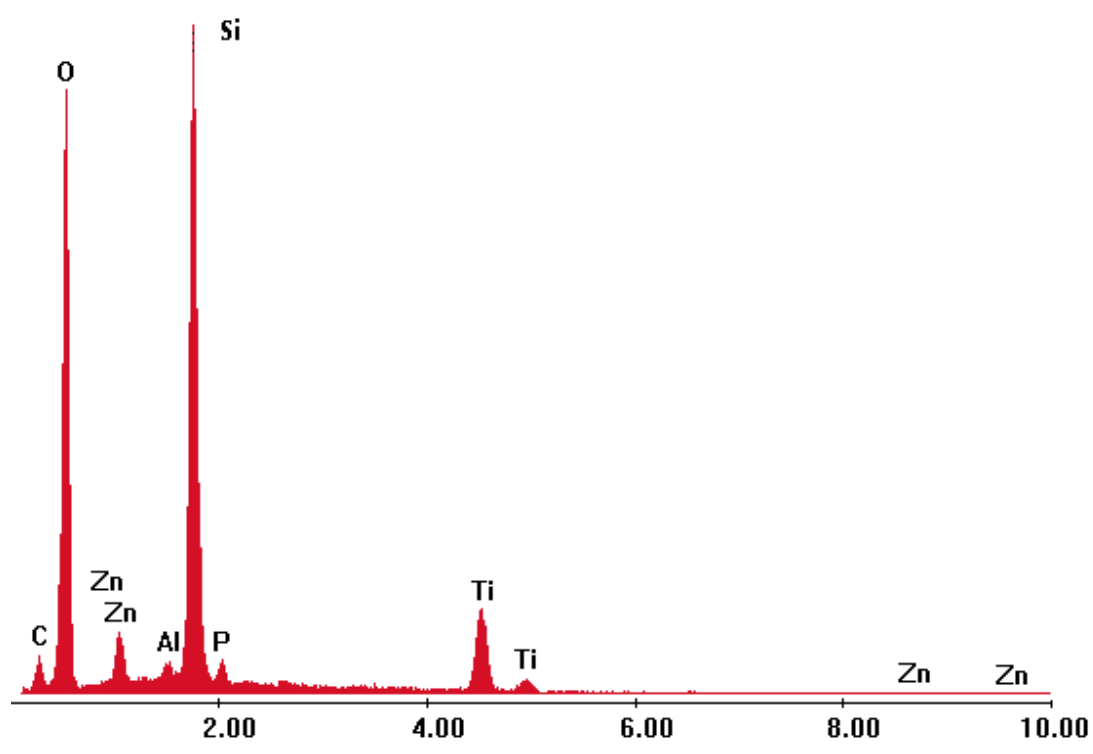

Figure 16. EDS spectra taken at point A in Figure 15. Spectra shows the presence of oxidized silicone contamination. 


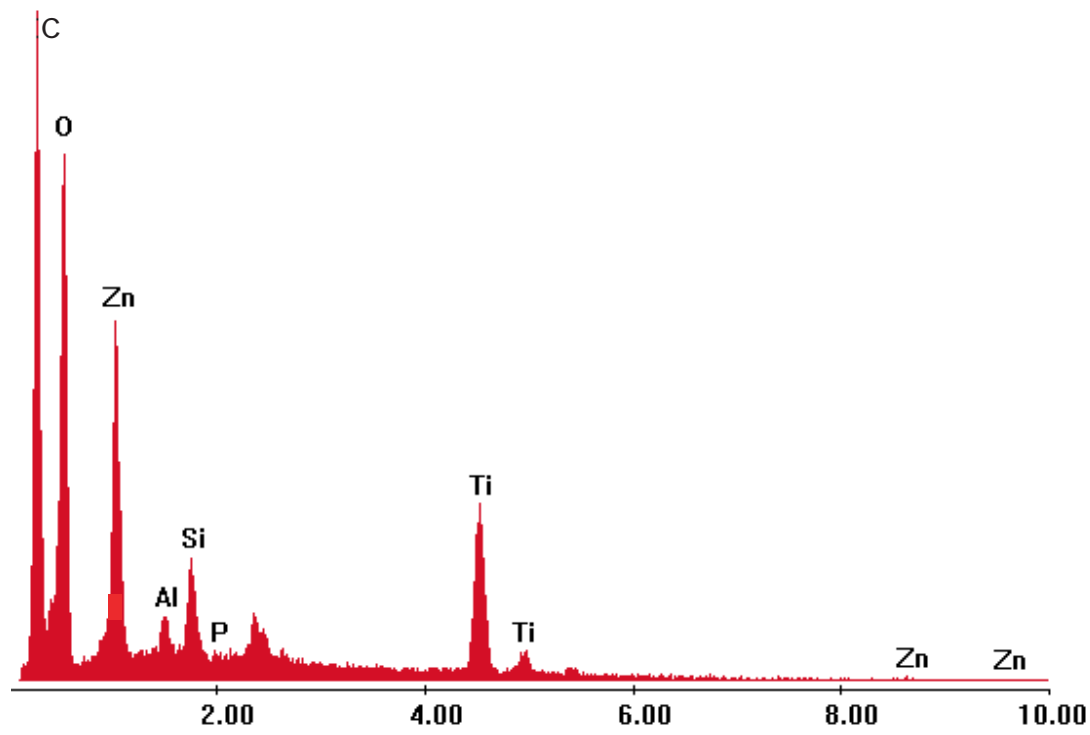

Figure 17. EDS spectra taken at point $B$ in Figure 15. Spectra similar to the cross-sectioned area, but with much larger $\mathrm{C}$ and $\mathrm{O}$ peaks.

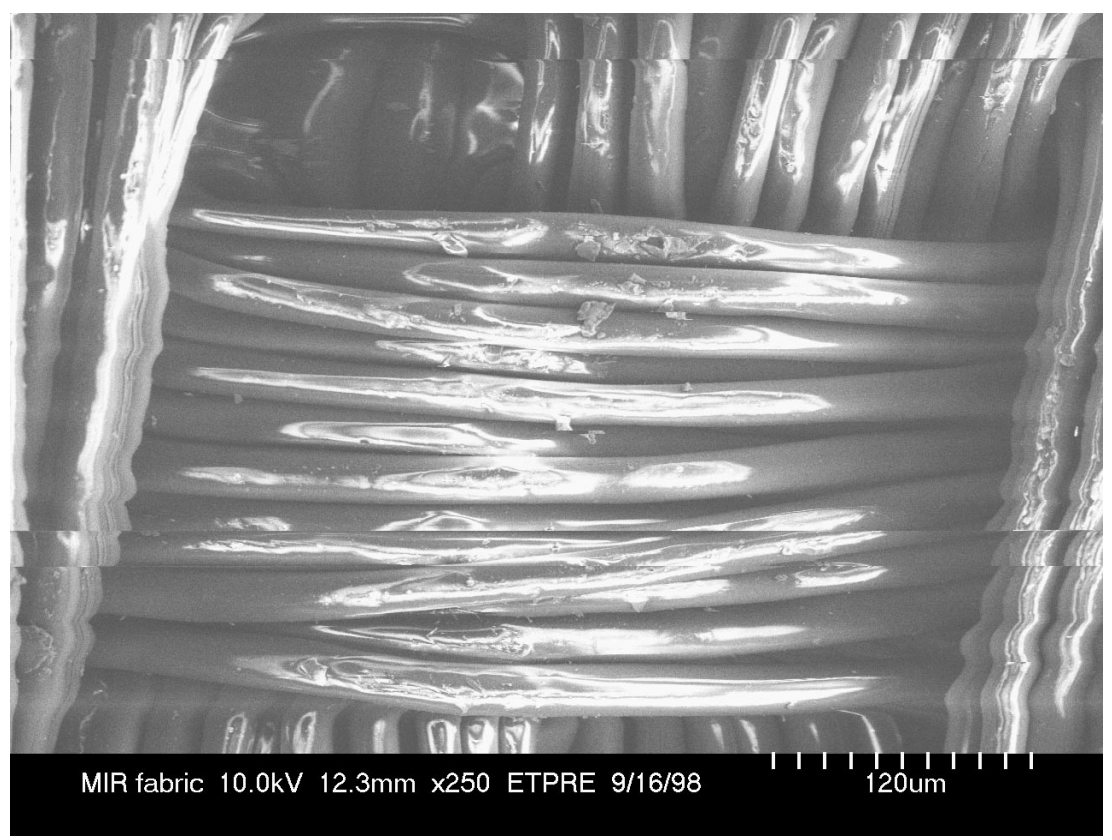

Figure 18. A protected, unexposed region on the topside of the handhold fabric.

Flexible Handhold Tape Over-Wrap. Unexposed "clean" areas of the handhold tape fabric were imaged. Both sides of the fabric were examined. The topside was on the same side of the fabric as the brown stain. The clean areas show some charging of the fibers during imaging as can be seen in figure 18 (bright white areas and distortion lines). EDS spectra for both the top and undersides of the fabric in the unexposed areas show the presence of only $\mathrm{C}$ and a small amount of $\mathrm{O}$, as shown in figure 19. This spectra was obtained for the topside area shown in figure 18.

The exposed brown stained area of the fabric was imaged and revealed a very thick layer of contaminant that has spalled off in some areas (possibly due to post-retrieval handling), as shown in figure 20. A near cross-section of the contaminant layer is seen in this image (to the right of point A), and at higher magnification the thickness was measured to be $\sim 1.6 \mu \mathrm{m}$ thick. EDS point spectra were obtained at two locations in figure 20 , one at an area where the contaminant has spalled-off (point A), and the second on top of the thick contaminant layer (point B). The corre- 


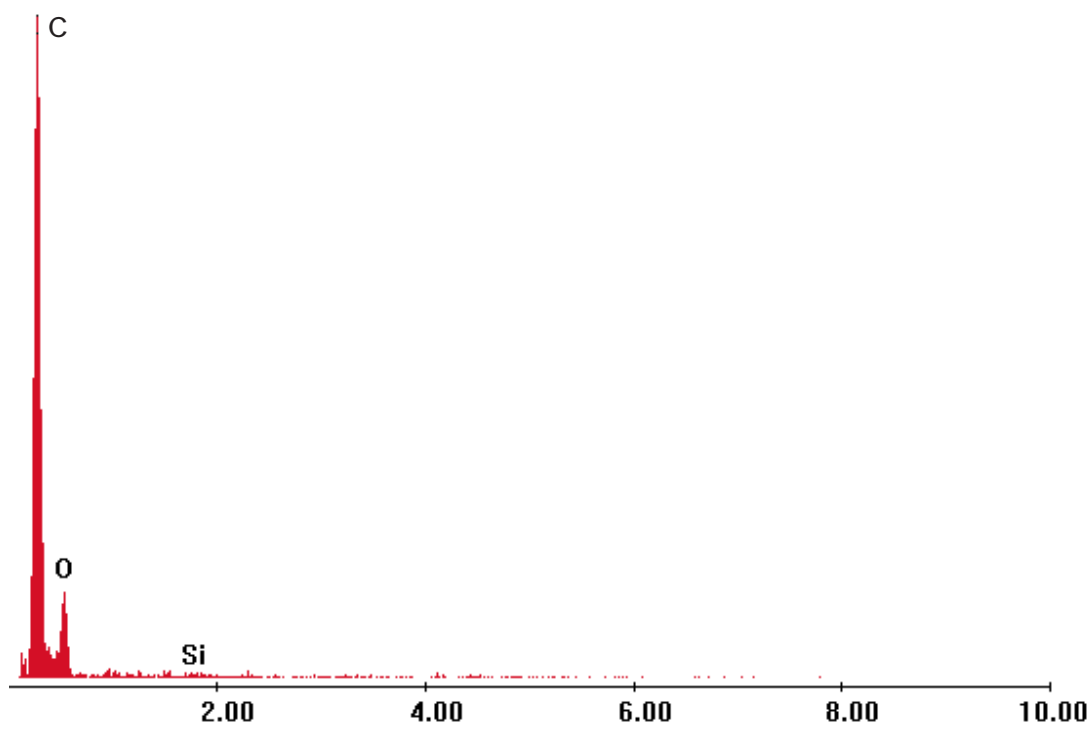

Figure 19. EDS spectra of the unexposed topside of the flexible handhold fabric, shown in Figure 18.

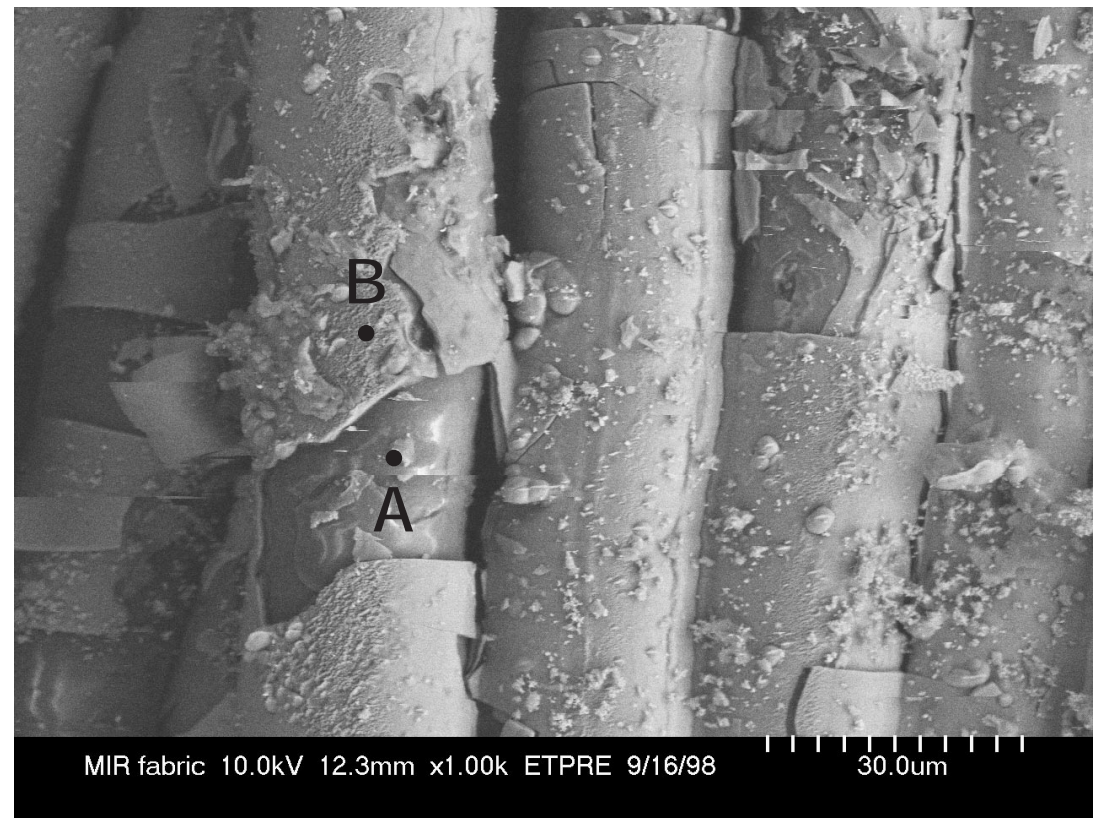

Figure 20. B rown exposed region of the flexible handhold fabric showing the presence of a very thick contaminant layer that has crazed and spalled off in certain areas.

sponding spectra for points A and B are shown in figures 21 and 22, respectively. Point A, where the contaminant has spalled off looks primarily like the unexposed fibers, mostly $\mathrm{C}$ with some $\mathrm{O}$. A very small Si peak is present. Point $\mathrm{B}$, focused on the contaminant film, is $\mathrm{Si}$ and $\mathrm{O}$, with almost no $\mathrm{C}$ present. The thick contaminant layer is clearly oxidized silicon, similar to the contaminant layer on the rigid handrail.

The contaminated fiber area did not charge during imaging like the clean fibers, or like silica would be expected to charge. Therefore, the contaminant layer appears to be electrically conductive. Minor variations in composition, impurity content, stoichiometry and other variables can have a significant effect on the electrical conductivity of insulating ceramic materials (ref. 4). For example, impurity elements can produce energy levels within the band gap and therefore increase the number of available charge carriers (ref. 5). In addition to possible stoichiometry 


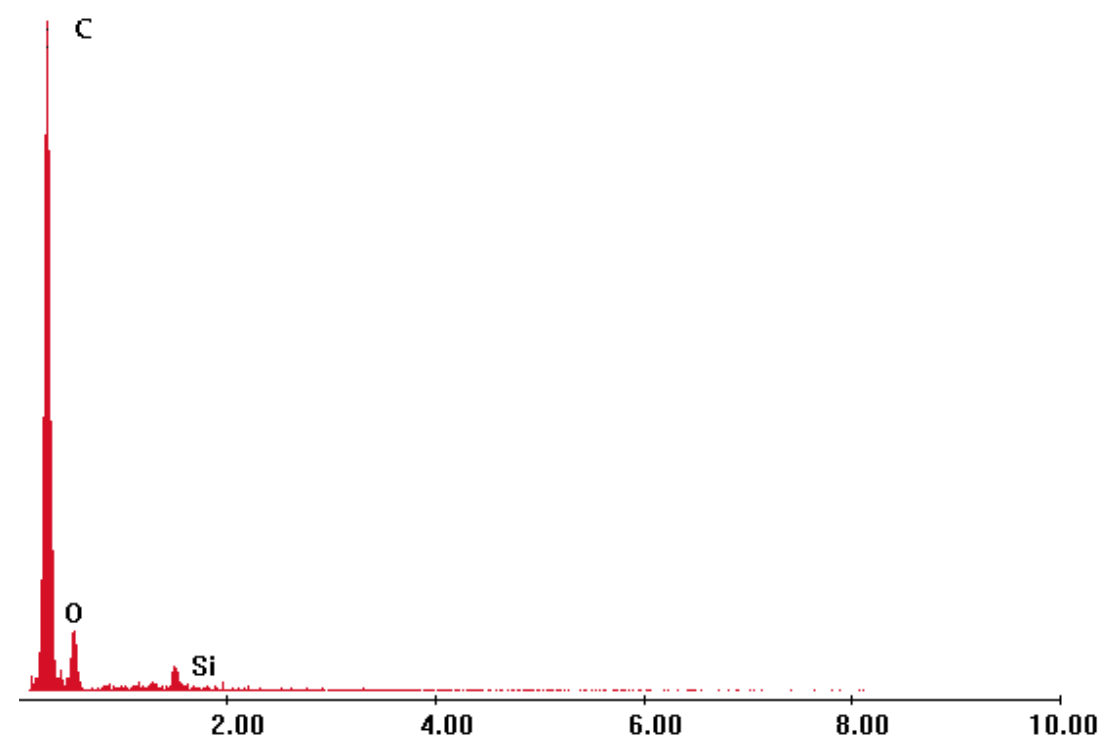

Figure 21. EDS spectra taken at point $\mathrm{A}$ in Figure 20.

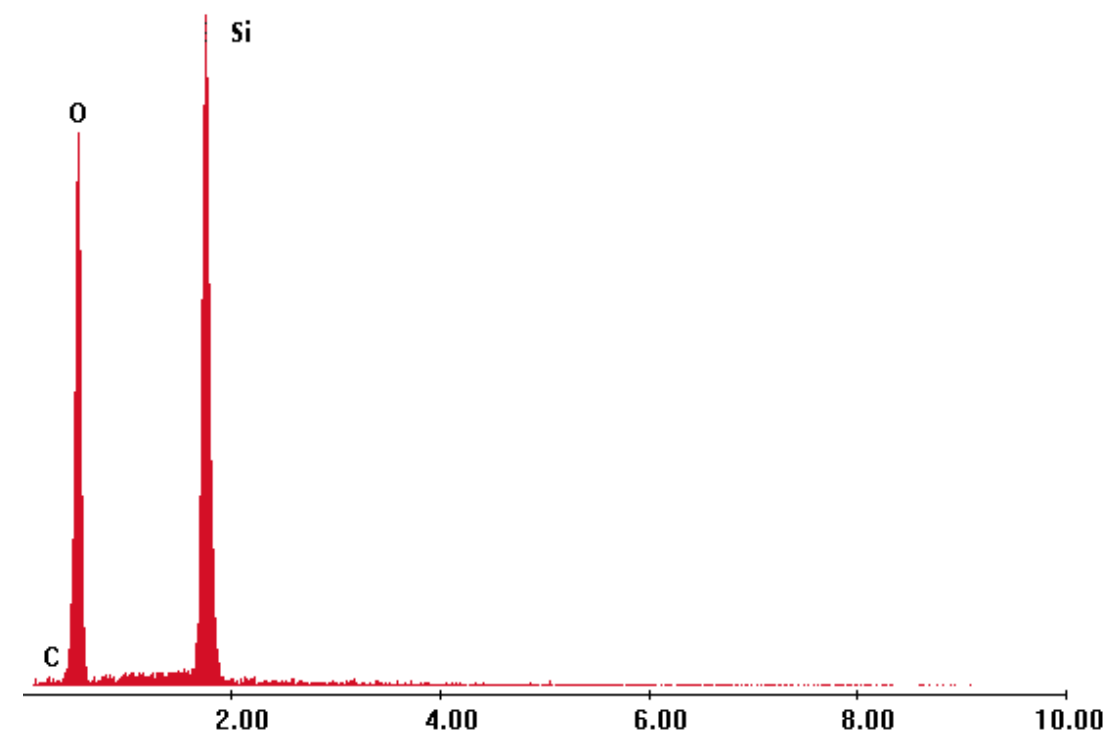

Figure 22. EDS spectra taken at point B in Figure 20. Spectra shows that the contaminant layer is oxidized silic on.

variations (compared to silica) or the presence of impurities in the oxidized silicon contaminant layer (both possibilities), the increased conductivity could also be attributed to a conductive carbon layer on the surface. EDS is a deep penetrating technique ( $\approx 1$ to $5 \mu \mathrm{m})$, and it may not be able to detect a very thin $\mathrm{C}$ surface layer. To verify if a conductive $\mathrm{C}$ layer and/or low level impurities are present, or to validate the stoichiometry of the oxidized silicon contaminant layer, surface sensitive analytical techniques such as ESCA are needed.

Figure 23 shows an area where the contaminant layer has spalled off the fibers in various locations while in space, and atomic oxygen has eroded the organic fibers. Several sections of fibers have been completely eroded away. This shows that the contaminant layer, which is resistant to atomic oxygen erosion, has become so thick that it became a source of particulate contamination in space. 


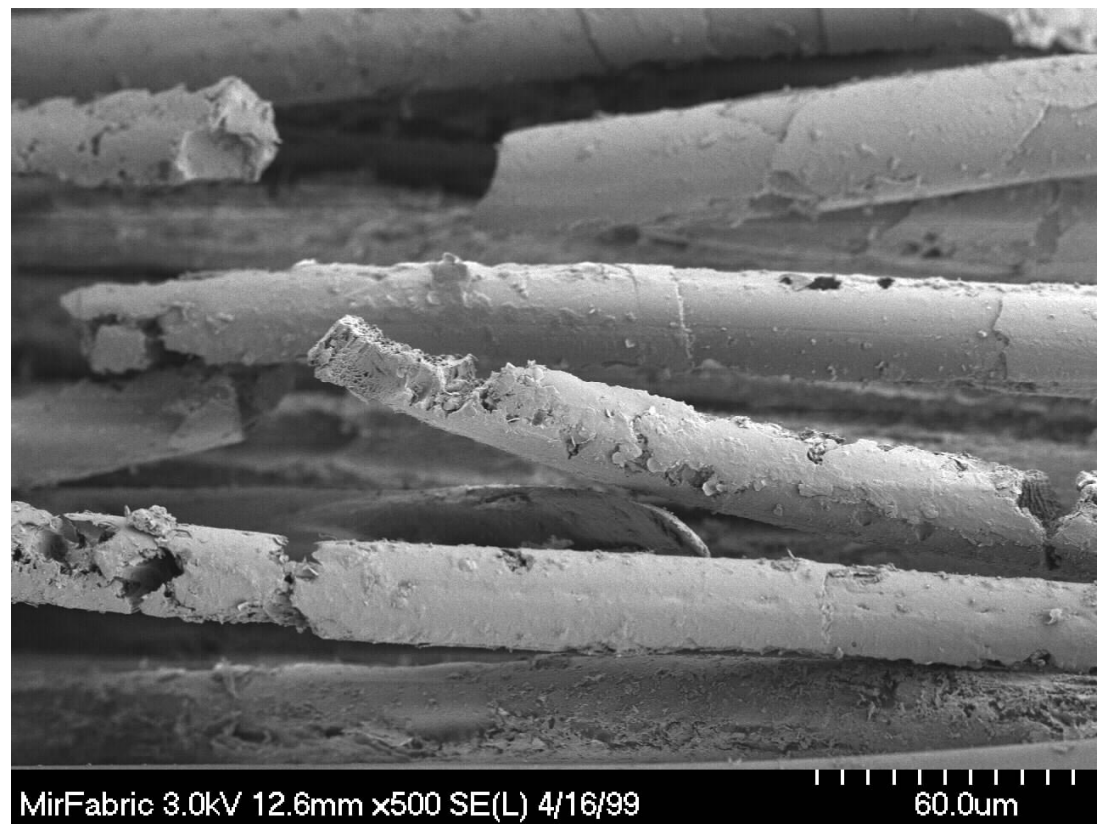

Figure 23. FESEM image of the contaminated flexible handhold tape fabric fibers. Atomic oxygen erosion has occurred in-space at locations where the contaminant layer has spalled off.

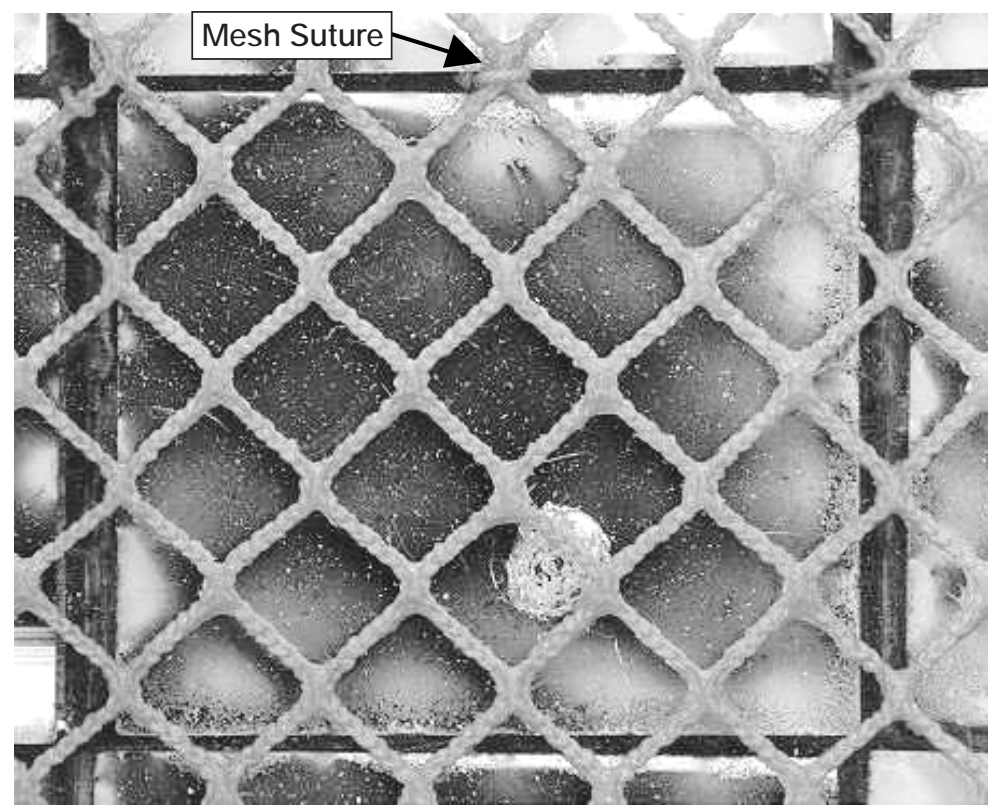

Figure 24. Backside of Mir solar cell (16-6) with mesh backing in place. Contaminant shadow lines (shaded by particulate pieces) point back towards the mesh suture at the top center of the cell (ref 7). 


\section{Discussion}

There is no silicon present in the unexposed over-wrap tape fabric, and very small amounts in the white paint. Therefore, the contaminant layer on both the handrail and the handholds is attributed to silicone contamination from other spacecraft materials that have been oxidized while in orbit by atomic oxygen.

As previously mentioned, the entire array was coated with contaminant films. The cover slides and the optical solar reflectors (OSR) on the backside of the arrays were covered with a nonuniform diffusely reflecting film (refs. 1 and 6). Figure 24 is a photograph of the backside of a solar cell (cell 16-6), and shows a structural mesh backing which was present over the OSR. The matte contaminant layer is clearly visible and appears to be thicker on the edges of the cell. The solar cells (front and back sides) were found to be contaminated by an organic silicone film which was converted to a silica coating by atomic oxygen exposure (refs. 1 and 6). Silicone compounds used to laminate the solar array panel are believed to be the source of contamination on the panels. For example, the source of the silicone contamination on the front and back of the cells visually appears to have evolved where reinforcement threads penetrated silicone potting strips between the cells (ref. 1). This can be seen in figure 24 by examining the suture thread holding the mesh backing in place at the top of the cell. Line-of-site contaminant shadows point towards the suture.

Based on these solar cell findings, and the fact that the handrail section facing the array appeared to be more contaminated than the space facing side, the source of contamination on the handrail samples appears to be primarily from silicones in the arrays themselves.

The returned contaminated solar array segment is very similar in design to the solar arrays being supplied by the Russians for the International Space Station (ISS). If the silicones used in the Russian supplied ISS solar arrays have the same volatile properties as the retrieved arrays, then they may be a significant source of silicone contamination on ISS.

\section{Summary and Conclusions}

Analyses have been conducted on two contaminated samples (a section of a rigid handrail and flexible handhold over-wrap tape fabric) from the Mir solar array retrieved after more than 10 years in the space environment. Optical microscopy and FESEM imaging have shown brown stained areas to have thick layers of contamination that have crazed and spalled off the surfaces in regions. An area where the cross-section of the contaminant is visible in FESEM imaging shows the film to be $\sim 1.6 \mu \mathrm{m}$ thick. Energy dispersive spectroscopy has revealed that the brown contaminant on both samples is composed of oxidized silicon with very little carbon content. There is no silicon present on the unexposed fabric overwrap, and very small amounts in the white paint. Therefore, the contaminant layer on both handrail samples is attributed to silicone contamination from other spacecraft materials that have been oxidized by atomic oxygen while in orbit. A significant source of the silicone contamination appears to be from the solar array itself. FESEM images of the handhold fabric show areas where the contaminant layer has spalled off the organic fibers and atomic oxygen erosion has occurred. This implies that flakes of the thick contaminant coating have spalled off while in space and therefore have been a source of particulate contamination.

\section{References}

1. Visentine, J., et. al.: "Mir Solar Array Return Experiment," AIAA 99-0100, 1999.

2. MIR Solar Array Returned Experiment (SARE) Archive System, NASA Langley Research Center, Hampton, Virginia, http://setas-www.larc.nasa.gov/sare/sare.html, provided by and the U.S. and Russian SARE Analysis Team Participants.

3. Visentine, J.: personal communication.

4. Kingery, W.D., Bowen, H.K. and Uhlmann, D.R.: Introduction to Ceramics, John Wiley \& Sons, NY, 1976.

5. Wyatt, O.H. and Dew-Hughes, D.: Metals, Ceramics and Polymers, Cambridge University Press, 1974.

6. Banks B.A., de Groh, K.K., Rutledge, S.K. and Haytas, C.A.: "Consequences of Atomic Oxygen Interaction with Silicone and Silicone Contamination on Surfaces in Low Earth Orbit," Proceedings of SPIE, Vol. 3784, 1999.

7. Courtesy of B. Banks at NASA Glenn Research Center. 
Public reporting burden for this collection of information is estimated to average 1 hour per response, including the time for reviewing instructions, searching existing data sources, gathering and maintaining the data needed, and completing and reviewing the collection of information. Send comments regarding this burden estimate or any other aspect of this collection of information, including suggestions for reducing this burden, to Washington Headquarters Services, Directorate for Information Operations and Reports, 1215 Jefferson Davis Highway, Suite 1204, Arlington, VA 22202-4302, and to the Office of Management and Budget, Paperwork Reduction Project (0704-0188), Washington, DC 20503.

\begin{tabular}{|l|l|l}
\hline 1. AGENCY USE ONLY (Leave blank) & $\begin{array}{c}\text { 2. REPORT DATE } \\
\text { October } 1999\end{array}$ & $\begin{array}{r}\text { 3. REPORT TYPE AND DATES COVERED } \\
\text { Technical Memorandum }\end{array}$ \\
\hline
\end{tabular}

4. TITLE AND SUBTITLE

5. FUNDING NUMBERS

Analyses of Contaminated Solar Array Handrail Samples Retrieved from Mir

6. AUTHOR(S)

Kim K. de Groh and Terry R. McCue

WU-632-1A-1E-00

7. PERFORMING ORGANIZATION NAME(S) AND ADDRESS(ES)

National Aeronautics and Space Administration

John H. Glenn Research Center at Lewis Field

Cleveland, Ohio 44135-3191

8. PERFORMING ORGANIZATION REPORT NUMBER

E-11835

9. SPONSORING/MONITORING AGENCY NAME(S) AND ADDRESS(ES)

10. SPONSORING/MONITORING AGENCY REPORT NUMBER

National Aeronautics and Space Administration

Washington, DC 20546-0001

NASA TM-1999-209399

\section{SUPPLEMENTARY NOTES}

Prepared for the 34th Intersociety Energy Conversion Engineering Conference sponsored by the Society of Automotive Engineers, Vancouver, British Columbia, Canada, August 1-5, 1999. Kim K. de Groh, NASA Glenn Research Center, and Terry R. McCue, Dynacs Engineering Company, Inc., Brook Park, Ohio. Responsible person, Kim K. de Groh, organization code 5480, (216) 433-2297.

12a. DISTRIBUTION/AVAILABILITY STATEMENT 12b. DISTRIBUTION CODE

Unclassified - Unlimited

Subject Categories: 18, 20, and 27

Distribution: Nonstandard

This publication is available from the NASA Center for AeroSpace Information, (301) 621-0390.

\section{ABSTRACT (Maximum 200 words)}

In January 1998 during the STS-89 mission, an eight section Russian solar array panel was retrieved after more than ten years exposure to the orbital space environment on the Russian space station Mir. Two darkened handrail samples from the Russian solar array have been evaluated for contamination; a section of a white paint covered rigid handrail and a section of woven fabric over-wrapped around a flexible handhold. The handrail samples were evaluated using optical microscopy (OM), field emission scanning electron microscopy (FESEM) and energy dispersive spectroscopy (EDS). Optical properties were also obtained. Microscopy has shown the discolored areas to have thick layers of contaminant that has crazed and spalled off in regions. Energy dispersive spectroscopy revealed that the brown contaminant is composed of oxidized silicon. No silicon was present on the unexposed fabric over-wrap, and very small amounts were present in the white paint. Therefore, the contaminant layer on both samples is attributed to silicone contamination from other spacecraft materials that have been oxidized by atomic oxygen while in orbit. A significant source of the silicone contamination appears to be from the solar array itself.

\section{SUBJECT TERMS}

Contamination; Silicone; Atomic oxygen; Thermal control paint; Mir; Solar array; Space environment

\begin{tabular}{|c|c|}
\hline $\begin{array}{c}\text { 17. SECURITY CLASSIFICATION } \\
\text { OF REPORT } \\
\text { Unclassified }\end{array}$ & $\begin{array}{c}\text { 18. SECURITY CLASSIFICATION } \\
\text { OF THIS PAGE } \\
\text { Unclassified }\end{array}$ \\
\hline
\end{tabular}

19. SECURITY CLASSIFICATION
OF ABSTRACT
Unclassified

Standard Form 298 (Rev. 2-89)

Prescribed by ANSI Std. Z39-18 298-102 